\title{
Faktor-faktor yang Berpengaruh Terhadap Minat Penggunaan Fasilitas E-Filing dalam Penyampaian SPT Secara Online
}

\section{Wayan Sugiartana1*, Made Mulia Handayani2}

${ }^{1}$ Program Studi Administrasi Bisnis STISPOL Wira Bhakti, Denpasar, Indonesia

${ }^{2}$ Fakultas of Ekonomi dan Bisnis, Universitas Ngurah Rai, Denpasar, Indonesia

\section{A R T I C L E I N F O}

\section{Article history:}

Received August 27, 2021

Revised August 29, 2021

Accepted October 14, 2021

Available online October 25, 2021

Kata Kunci:

Kegunaan, Kemudahan, Teknologi Informasi

Keywords:

Usefulness, Ease of Use, Information Technology

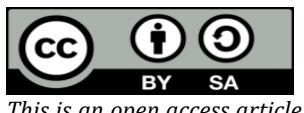

This is an open access article under the $C C$ BY-SA license.

Copyright (C) 2021 by Author. Published by Universitas Pendidikan Ganesha.

\begin{abstract}
A B S T R A K
Direktorat Jenderal Pajak dalam usaha mengantisipasi perkembangan informasi dan teknologi, berusaha untuk memenuhi aspirasi wajib pajak dengan mempermudah tata cara pelaporan SPT baik itu SPT masa maupun SPT tahunan melalui $e$-filing. Namun saat ini belum semua wajib pajak menggunakan $e$-filing karena kurangnya sosialisasi dari Direktorat Jendral Pajak (DJP) atau mungkin wajib pajak belum bisa menerima teknologi baru dalam pelaporan pajaknya. Penelitian ini bertujuan untuk membuktikan secara empiris pengaruh persepsi kegunaan, persepsi kemudahan, kesiapan teknologi informasi wajib pajak dan efektivitas sistem terhadap minat penggunaan fasilitas $e$-filing dalam penyampaian SPT secara online. Jumlah sampel penelitian sebagai subjek dalam penelitian ini ditentukan dengan rumus Slovin sebanyak 100 orang wajib pajak orang pribadi. Data dianalisis dengan menggunakan uji asumsi klasik, analisis regresi linier berganda, uji kelayakan model dan uji hipotesis (uji t). Hasil penelitian menunjukkan persepsi kegunaan, persepsi kemudahan, kesiapan teknologi informasi wajib pajak, dan rfektivitas sistem berpengaruh positif terhadap minat penggunaan fasilitas e-filing dalam penyampaian SPT secara online. Implikasi hasil penelitian, Ditjen Pajak diharapkan meningkatkan kualitas pelayanannya dalam memperkenalkan e-filing, meningkatkan sosialisasi $e$-filing dan meningkatkan fasilitas sistem e-filing baik dalam kecepatan akses, memperbanyak ASP atau koneksi terhadap perangkat sistem akuntansi yang dimiliki oleh wajib pajak.
\end{abstract}

\section{A B S T R A C T}

The Directorate General of Taxes in an effort to anticipate the development of information and technology, seeks to meet the aspirations of taxpayers by simplifying the procedures for reporting SPT, both mass SPT and annual SPT through efiling. However, currently not all taxpayers use e-filing due to lack of socialization from the Directorate General of Taxes (DGT) or maybe taxpayers have not been able to accept new technology in their tax reporting. This study aims to empirically prove the effect of perceived usefulness, perceived convenience, readiness of taxpayers' information technology and system effectiveness on interest in using e-filing facilities in submitting online tax returns. The number of research samples as subjects in this study was determined by the Slovin formula as many as 100 individual taxpayers. Data were analyzed using classical assumption test, multiple linear regression analysis, model feasibility test and hypothesis testing ( $t$ test). The results showed that perceived usefulness, perceived convenience, readiness of taxpayers' information technology, and system effectiveness had a positive effect on interest in using e-filing facilities in submitting online tax returns. The implication of the research results is that the Directorate General of Taxes is expected to improve the quality of its services in introducing e-filing, increasing e-filing socialization and improving e-filing system facilities both in speed of access, increasing ASP or connection to accounting system equipment owned by taxpayers.

\section{PENDAHULUAN}

Pajak merupakan sebuah perwujudan dari kewajiban kenegaraan dan peran serta wajib pajak untuk secara langsung dan bersama-sama melaksanakan kewajiban perpajakan untuk pembiayaan Negara dan pembangunan nasional(Maria \& Nurlaela, 2020; Salamah \& Furqon, 2020). Pajak menjadi salah satu sumber pendapatan terbesar bagi negara, dimana kontribusi pajak bagi pendapatan negara yakni mencapai 70-80\% pada tahun 2015-2019 dari total penerimaan negara selain dari sektor migas dan non migas (Irawati et al., 2020; Mineri \& Paramitha, 2021). Hal ini menunjukkan bahwa pajak sangat mempengaruhi penerimaan negara. Dalam proses pelaksanaannya pajak memiliki fungsi sebagai budgetair, yang berarti bahwa pajak sebagai sumber pengahasilan negara yang digunakan untuk membiayai sebagian besar pengeluaran negara seperti pengeluaran dalam pembangunan serta pengeluaran dalam proses pelayanan masyarakat (Rahmi et al., 2020; Viva et al., 2019). Wajib pajak dapat dikenakan kepada individu ataupun 
Lembaga (Rusli \& Nainggolan, 2021). Sebagai sumber keuangan negara, pemerintah berupaya memaksimalkan setiap pos penerimaan negara, termasuk pajak (Harjowiryono, 2019; Suparman, 2021; Viva et al., 2019). Target penerimaan pajak setiap tahunnya meningkat sesuai dengan meningkatnya kebutuhan pembiayaan pengeluaran negara (Biettant et al., 2020; Sakir et al., 2021). Realisasi penerimaan pajak yang meningkat tentu akan memudahkan pelaksanaan pembangunan maupun pelayanan kepada masyarakat yang dibiayai oleh pendapatan negara (Surya et al., 2019). Dengan meningkatnya penerimaan pajak, maka akan meningkatkan pembangunan dan memudahkan pembiayaan untuk pos-pos yang telah diproyeksikan dalam APBN (Harefa, 2019).

Pelaksanaan pembayaran pajak pada umumnya dilaksanakan melalui proses pembayaran langsung ke kantor pajak atau melalui pemotongan gaji oleh perusahaan terkait (Kolatung, 2021). Hanya saja di masa pandemi covid-19 seperti saat ini realisasi penerimaan pajak sepanjang 2020 mengalami penurunan yang cukup dalam yaitu hanya mencapai 89,3 persen dari target yang ditetapkan (Suparman, 2021). Pelaksanaan terobosan untuk mengoptimalkan penerimaan pajak terus dilakukan pemerintah melalui pelaksanaan kebijakan-kebijakan yang dikeluarkan Direktorat Jenderal Pajak guna menunjang peningkatkan penerimaan pajak. Adapun kebijakan yang dikeluarkan yakni melalui modernisasi administrasi perpajakan yang tujuannya untuk memudahkan wajib pajak dalam melaporkan kewajiban pajak mereka (Alvin \& Apollo, 2020). Salah satu inovasi yang dikembangkan yakni E-filing yang mampu memudahkan masyarakat serta lembaga untuk memenuhi kewajibannya dalam membayar pajak (Maryan, 2019). E-filing merupakan sebuah sistem pelaporan atau penyampaian pajak dengan SPT secara elektronik yang dilakukan melalui sistem on-line yang real time, bertujuan untuk menyediakan fasilitas pelaporan SPT secara online kepada Wajib Pajak (Haryaningsih \& Juniwati, 2020; Sarroh, 2019; Sumarlan et al., 2020). Wajib pajak Orang Pribadi dapat melakukannya dari rumah atau tempatnya bekerja, sedangkan Wajib Pajak Badan dapat melakukannya dari kantor (Chrisandita \& Sukartha, 2021). Hal ini akan dapat membantu wajib pajak mengurangi biaya dan waktu yang dibutuhkan oleh wajib pajak untuk melaporkan SPT ke Kantor Pajak secara benar dan tepat waktu (Nasution \& Ferrian, 2017). Hanya saja untuk saat ini belum semua wajib pajak mampu menggunakan e-filing karena kurangnya sosialisasi dari Direktorat Jendral Pajak serta kurangnya kemampuan penggunaan teknologi baru dalam proses pelaporan pajak (Dewi, 2019; Muhammad \& Mildawati, 2020).

Adanya pengembangan teknologi baru dalam pembayaran pajak menimbulkan berbagai macam persepsi dan prilaku bagi masyarakat (Dewi, 2021). Perilaku yang dimaksud dalam ini adalah minat penggunaan fasilitas $e$-filing dalam penyampaian SPT secara online, yaitu keinginan (minat) dari wajib pajak untuk menggunakan fasilitas e-filing dalam penyampaian SPT secara online (Hasari, 2019; Nurhayati \& Hidayat, 2019). Terdapat beberapa faktor yang mempengaruhi minat penggunaan $e$-filing bagi masyarakat wajib pajak. Beberapa penelitian yang telah dilakukan sebelumnya mengungkapkan bahwa faktor yang mempengaruhi minat wajib pajak dapat dilihat dari beberapa persepsi yakni persepsi kegunaan, kemudahan, kerahasiaan, kerumitan, kesiapan teknologi informasi berpengaruh signifikan terhadap minat wajib pajak orang pribadi dalam menggunakan e-filing (Pu'o et al., 2018). Hasil penelitian lainnya juga mengungkapkan bahwa E-filing untuk hotel dan restoran di wilayah perbatasan RI-RDTL, Pengetahuan pajak tidak berpengaruh positif dan tidak signifikan terhadap minat penggunaan system e-filing untuk hotel dan restoran di wilayah perbatasan RI-RDTL, Persepsi kemudahan berpengaruh positif dan signifikan terhadap minat penggunaan system e-filing untuk hotel dan restoran di wilayah perbatasan RI-RDTL, Pemahaman teknologi informasi tidak memiliki pengaruh positif dan tidak signifikan terhadap minat penggunaan system e-filing untuk hotel dan restoran di wilayah perbatasan RI-RDTL (Simu \& Hariadi, 2021). Penelitian selanjutnya juga mengungkapkan hal serupa yakni persepsi kemudahan, persepsi kegunaan serta keamanan dan kerahasiaan berpengaruh positif terhadap minat wajib pajak orang pribadi menggunakan e-filing, pemahaman internet tidak mampu memoderasi pengaruh persepsi kemudahan dan persepsi kegunaan terhadap minat menggunakan e-filing sedangkan pemahaman internet mampu memoderasi pengaruh keamanan dan kerahasiaan terhadap minat menggunakan e-filing (Asih et al., 2019).

Berdasarkan hasil tersebut dapat dikatakan bahwa terdapat 5 faktor yang mempangaruhi minat Penggunaan Fasilitas E-Filing dalam Penyampaian SPT Secara Online diantaranya yakni faktor kegunaan, kemudahan, kerahasiaan, kerumitan, kesiapan teknologi informasi. Hanya saja pada penelitian sebelumnya belum terdapat kajian yang berfokus pada konsumen daerah kabupaten badung. Sehingga penelitian ini difokuskan pada pengkajian faktor yang mempangaruhi minat Penggunaan Fasilitas E-Filing dalam Penyampaian SPT Secara Online di wilayah kabupaten badung, dengan tujuan untuk membuktikan secara empiris pengaruh persepsi kegunaan, persepsi kemudahan, kesiapan teknologi informasi wajib pajak dan efektivitas sistem terhadap minat penggunaan fasilitas e-filing dalam penyampaian SPT secara online di Kantor Pelayanan Pajak Pratama Badung Utara dan Badung Selatan. 


\section{METODE}

Jenis penelitian ini termasuk dalam penelitian kuantitatif dengan pendekatan penelitian deskriptif dan analisis asosiatif. Pendekatan assosiatif merupakan rumusan masalah penelitian yang bersifat menanyakan hubungan antara dua variabel atau lebih. Pendekatan assosiatif digunakan untuk mengetahui pengaruh persepsi kegunaan, persepsi kemudahan, kesiapan teknologi informasi wajib pajak dan efektivitas sistem terhadap minat penggunaan fasilitas e-filing dalam penyampaian SPT secara online. Penelitian ini dilakukan di Kantor Pelayanan Pajak Pratama Badung Utara yang beralamat di Jalan Ahmad Yani No.100, Dauh Puri Kaja, Kecamatan Denpasar Utara, Kota Denpasar dan Kantor Pelayanan Pajak Pratama Badung Selatan yang beralamat di Jalan Tantular No.4, Dangin Puri Klod, Kecamatan Denpasar Timur, Kota Denpasar. Obyek dalam penelitian ini adalah persepsi kegunaan, persepsi kemudahan, kesiapan teknologi informasi wajib pajak, efektivitas sistem dan minat penggunaan fasilitas $e$-filing dalam penyampaian SPT secara online. Subjek dalam penelitian ini adalah wajib pajak orang pribadi yang terdaftar di Kantor Pelayanan Pajak Pratama Badung Utara dan Badung Selatan tahun 2020. Hasil perhitungan dengan rumus Slovin diketahui jumlah sampel penelitian sebanyak 100 orang wajib pajak orang pribadi. Penentuan sampel dilakukan secara langsung dengan teknik sampling accidental. Pengumpulan data dilakukan dengan menggunakan kuesioner. Data hasil penyebaran kuesioner dikuantitatifkan dengan memberikan skor pada masing-masing jawaban. Metode penskalaan dalam penelitian ini adalah menggunakan skala Likert dengan skor 1-5. Alat analisis data terdiri dari uji asumsi klasik, analisis regresi linier berganda, uji kelayakan model dan uji hipotesis (uji t).

\section{HASIL DAN PEMBAHASAN}

Hasil

Teknik analisis data yang digunakan dalam penelitian ini adalah analisis regresi linier berganda. Sebelum menggunakan analisis regresi linier berganda maka perlu dilakukan uji asumsi klasik untuk mengetahui kelayakan model regresi sehingga memberikan hasil prediksi yang baik. Uji asumsi klasik dianalisis dengan program SPSS 20.0 for Windows, terdiri dari uji multikolonieritas, uji heteoskedastisitas dan uji normalitas. Asumsi multikolinearitas menyatakan bahwa dalam regresi berganda gejala korelasi seharusnya tidak ada. Mendeteksi ada atau tidaknya gejala ini diketahui dari nilai tolerance dan VIF seperti pada Tabel 1.

Tabel 1. Hasil Uji Multikolinearitas

\begin{tabular}{llccl}
\hline \multirow{2}{*}{ No } & \multicolumn{1}{c}{ Variabel Bebas } & \multicolumn{2}{c}{ Collinearity Statistic } & \multirow{2}{*}{ Keterangan } \\
\cline { 3 - 4 } & Polerance & VIF & \\
\hline 1 & Persepsi kegunaan $\left(\mathrm{X}_{1}\right)$ & 0,324 & 3,084 & Non multikolinearitas \\
2 & Persepsi kemudahan $\left(\mathrm{X}_{2}\right)$ & 0,339 & 2,952 & Non multikolinearitas \\
3 & Kesiapan teknologi informasi & 0,355 & 2,817 & Non multikolinearitas \\
& wajib pajak $\left(\mathrm{X}_{3}\right)$ & & & \\
4 & Efektivitas sistem $\left(\mathrm{X}_{4}\right)$ & 0,589 & 1,698 & \multirow{2}{*}{ Non multikolinearitas } \\
\hline
\end{tabular}

Berdasarkan Tabel 1 diketahui bahwa angka tolerance lebih dari 0,10 atau kurang dari 1,00 dan nilai VIF (Varian Inflation Factor) kurang dari 10 menjelaskan tidak terjadi gejala multikolinearitas atau tidak terjadi korelasi diantara variabel persepsi kegunaan, persepsi kemudahan, kesiapan teknologi informasi wajib pajak dan efektivitas sistem, atau dengan kata lain persamaan regresi memenuhi hasil prediksi yang baik. Uji heteroskedastisitas bertujuan untuk menguji apakah dalam model regresi terjadi ketidaksamaan variance dari residual antara satu pengamatan dengan pengamatan lainnya. Hasil uji heteroskedastisitas menunjukkan bahwa probabilitas signifikansi variabel persepsi kegunaan adalah 0,493 $>\alpha=0,05$, persepsi kemudahan adalah $0,132>\alpha=0,05$, kesiapan teknologi informasi wajib pajak adalah $0,729>\alpha=0,05$, dan efektivitas sistem adalah $0,758>\alpha=0,05$. Hasil ini menunjukkan bahwa koefisien regresi nilai absolut residual tidak signifikan, sehingga tidak terjadi heteroskedastisitas pada variabel persepsi kegunaan, persepsi kemudahan, kesiapan teknologi informasi wajib pajak dan efektivitas sistem. Analisis selanjutnya yakni dilakukan uji normalitas dengan tujuan untuk menguji apakah dalam sebuah model regresi, variabel terganggu atau residual memiliki distribusi normal. Mendeteksi apakah residual berdistribusi normal atau tidak digunakan analisis uji statistik. Uji statistik yang digunakan untuk menguji normalitas residual adalah uji statistik non-parametrik Kolmogrov-Smirnov (K-S), seperti pada Tabel 2. 
Tabel 2. Hasil Uji Kolmogorov-Smirnov

\begin{tabular}{lc}
\hline & Unstandardised Residual \\
\hline $\mathrm{N}$ & 100 \\
Kolmogorov-Smirnof $Z$ & 1,133 \\
Asymp. Sig (2-tailed) & 0,153 \\
\hline
\end{tabular}

Tabel 2 menunjukkan bahwa nilai Kolmogorov-Smirnof sebesar 1,133 dengan tingkat probabilitas sebesar 0,153. Nilai tingkat probabilitas atau Asymp. Sig (2-tailed) yang lebih besar dari level of significant 0,05 , berarti model regresi memenuhi asumsi normalitas atau data berdistribusi normal. Sehingga berdasarkan hasil uji asumsi klasik maka diketahui pada persamaan regresi tidak terjadi multikolinearitas, tidak terjadi heteroskedastisitas dan distribusi data adalah normal sehingga model regresi linier berganda bisa digunakan karena mendapatkan hasil prediksi yang baik. Setelah dilaksanakan uji asumsi klasik, penelitian kemudian dilanjutkan pada analisis regresi linier yang dilakukan untuk mengetahui pengaruh antara persepsi kegunaan, persepsi kemudahan, kesiapan teknologi informasi wajib pajak dan efektivitas sistem terhadap minat penggunaan fasilitas e-filing dalam penyampaian SPT secara online yaitu berubahnya minat penggunaan fasilitas e-filing dalam penyampaian SPT secara online akibat perubahan persepsi kegunaan, persepsi kemudahan, kesiapan teknologi informasi wajib pajak. Rekapitulasi hasil analisis regresi menggunakan program SPSS 20.0 for Windows.

Berdasarkan hasil analisis diketahui bahwa persamaan regresi linier berganda adalah: $Y=0,588 \mathrm{X}_{1}$ $+0,154 X_{2}+0,150 X_{3}+0,119 X_{4}$ menjelaskan bahwa persepsi kegunaan mempunyai koefisien regresi sebesar 0,588 (positif) artinya meningkatnya persepsi kegunaan akan diikuti oleh meningkatnya minat penggunaan fasilitas e-filing dalam penyampaian SPT secara online, dengan asumsi variabel persepsi kemudahan, kesiapan teknologi informasi wajib pajak dan efektivitas sistem adalah konstan. Persepsi kemudahan mempunyai koefisien regresi sebesar 0,154 (positif) artinya meningkatnya persepsi kemudahan akan diikuti oleh meningkatnya minat penggunaan fasilitas e-filing dalam penyampaian SPT secara online, dengan asumsi variabel persepsi kegunaan, kesiapan teknologi informasi wajib pajak dan efektivitas sistem adalah konstan. Kesiapan teknologi informasi wajib pajak mempunyai koefisien regresi sebesar 0,150 (positif) artinya meningkatnya kesiapan teknologi informasi wajib pajak akan diikuti oleh meningkatnya minat penggunaan fasilitas e-filing dalam penyampaian SPT secara online, dengan asumsi variabel persepsi kegunaan, persepsi kemudahan dan efektivitas sistem adalah konstan. Efektivitas sistem mempunyai koefisien regresi sebesar 0,119 (positif) artinya meningkatnya efektivitas sistem akan diikuti oleh meningkatnya minat penggunaan fasilitas e-filing dalam penyampaian SPT secara online, dengan asumsi variabel persepsi kegunaan, persepsi kemudahan dan kesiapan teknologi informasi wajib pajak adalah konstan. Selanjutnya pada Uji goodness of fit atau uji kelayakan model yang dilakukan untuk mengukur ketepatan fungsi regresi sampel dalam menaksir nilai aktual. Secara statistik uji goodness of fit dapat dilakukan melalui pengukuran nilai koefisien determinasi dan nilai statistik F. Analisis determinasi digunakan untuk mengetahui seberapa besar kontribusi secara simultan perubahan variabel persepsi kegunaan, persepsi kemudahan, kesiapan teknologi informasi wajib pajak dan efektivitas sistem mampu menjelaskan perubahan variabel minat penggunaan fasilitas e-filing dalam penyampaian SPT secara online. Koefisien determinasi diketahui dari nilai $\mathrm{R}^{2}$ dalam persentase dengan menggunakan program SPSS 20.0 for Windows. Nilai koefisien determinasi dapat dilihat pada Tabel Model Summary yang disajikan seperti pada Tabel 3.

Tabel 3. Tabel Model Summary

\begin{tabular}{lcccc}
\hline Model & $\mathbf{R}$ & $\mathbf{R}$ Square & $\begin{array}{c}\text { Adjusted } \\
\mathbf{R} \text { Square }\end{array}$ & Std. Error of the Estimate \\
\hline 1 & 0,915 & 0,837 & 0,831 & 1,164 \\
\hline
\end{tabular}

Berdasarkan Tabel 3 diperoleh koefisien determinasi dengan $\mathrm{R}^{2}$ adalah 0,837 menunjukkan bahwa perubahan variabel persepsi kegunaan, persepsi kemudahan, kesiapan teknologi informasi wajib pajak dan efektivitas sistem secara simultan berkontribusi terhadap perubahan variabel minat penggunaan fasilitas e-filing dalam penyampaian SPT secara online di Kantor Pelayanan Pajak Pratama Badung Utara dan Badung Selatan sebesar $83,70 \%$, sedangkan sisanya $16,30 \%$ dijelaskan variabel lain yang tidak dibahas dalam penelitian ini. Uji $\mathrm{F}$ atau F-test digunakan untuk menguji kelayakan model regresi yang digunakan. Signifikan F-test diperoleh dari hasil regresi pada tabel ANova dengan menggunakan program SPSS 20.0 for Windows. Level of significant menggunakan derajat kepercayaan 95 persen atau tingkat kesalahan 5 persen $(\alpha=0,05)$. Apabila tingkat signifikansi $\mathrm{F}$ (sign. F) $<\alpha=0,05$ maka model regresi layak digunakan, sebaliknya apabila nilai signifikansi $F$ (sign. F) $\geq \alpha=0,05$ maka model regresi tidak layak digunakan. Berdasarkan hasil 
analisis diperoleh F-hitung adalah 122,340 dengan nilai signifikansi F sebesar 0,000 lebih kecil dari 5 persen $(\alpha=0,05)$, berarti model regresi layak digunakan dan selanjutnya dapat dilakukan pengujian hipotesis.

Selanjutnya pada Uji t atau t-test digunakan untuk menguji signifikansi koefisien regresi sehingga diketahui apakah variabel persepsi kegunaan, persepsi kemudahan, kesiapan teknologi informasi wajib pajak dan efektivitas sistem berpengaruh atau tidak terhadap variabel minat penggunaan fasilitas $e$-filing dalam penyampaian SPT secara online. Signifikan atau tidaknya hasil regresi diketahui dengan menggunakan program SPSS 20.0 for Windows. Level of significant menggunakan derajat kepercayaan 95 persen atau tingkat kesalahan 5 persen $(\alpha=0,05)$. Jika nilai signifikansi t (sign. $t)<\alpha=0,05$ maka pengaruh adalah signifikan, sedangkan jika nilai signifikansi t (sign. $t$ ) $\geq \alpha=0,05$ maka pengaruh adalah tidak signifikan. Signifikan t-test diperoleh dari hasil regresi pada tabel coefficents dengan menggunakan program SPSS 20.0 for Windows. Hasil uji signifikansi variabel persepsi kegunaan, persepsi kemudahan, kesiapan teknologi informasi wajib pajak dan efektivitas sistem terhadap minat penggunaan fasilitas $e$-filing dalam penyampaian SPT secara online. Koefisien regresi persepsi kegunaan adalah sebesar 0,588 menunjukkan arah koefisien regresi positif, dengan pengujian signifikansi (t-test) persepsi kegunaan terhadap minat penggunaan fasilitas $e$-filing dalam penyampaian SPT secara online diperoleh nilai signifikansi sebesar 0,000 lebih kecil dari 5 persen $(\alpha=0,05)$, berarti persepsi kegunaan berpengaruh positif terhadap minat penggunaan fasilitas e-filing dalam penyampaian SPT secara online di Kantor Pelayanan Pajak Pratama Badung Utara dan Badung Selatan. Hasil ini menerima hipotesis pertama $\left(\mathrm{H}_{1}\right)$.

Koefisien regresi persepsi kemudahan adalah sebesar 0,154 menunjukkan arah koefisien regresi positif, dengan pengujian signifikansi (t-test) persepsi kemudahan terhadap minat penggunaan fasilitas $e$ filing dalam penyampaian SPT secara online diperoleh nilai signifikansi sebesar 0,032 lebih kecil dari 5 persen $(\alpha=0,05)$, berarti persepsi kemudahan berpengaruh positif terhadap minat penggunaan fasilitas $e$ filing dalam penyampaian SPT secara online di Kantor Pelayanan Pajak Pratama Badung Utara dan Badung Selatan. Hasil ini menerima hipotesis kedua $\left(\mathrm{H}_{2}\right)$. Koefisien regresi kesiapan teknologi informasi wajib pajak adalah sebesar 0,150 menunjukkan arah koefisien regresi positif, dengan pengujian signifikansi (t-test) kesiapan teknologi informasi wajib pajak terhadap minat penggunaan fasilitas $e$-filing dalam penyampaian SPT secara online diperoleh nilai signifikansi sebesar 0,033 lebih kecil dari 5 persen $(\alpha=0,05)$, berarti kesiapan teknologi informasi wajib pajak berpengaruh positif terhadap minat penggunaan fasilitas $e$-filing dalam penyampaian SPT secara online di Kantor Pelayanan Pajak Pratama Badung Utara dan Badung Selatan. Hasil ini menerima hipotesis ketiga $\left(\mathrm{H}_{3}\right)$. Koefisien regresi efektivitas sistem adalah sebesar 0,119 menunjukkan arah koefisien regresi positif, dengan pengujian signifikansi (t-test) efektivitas sistem terhadap minat penggunaan fasilitas e-filing dalam penyampaian SPT secara online diperoleh nilai signifikansi sebesar 0,029 lebih kecil dari 5 persen $(\alpha=0,05)$, berarti efektivitas sistem berpengaruh positif terhadap minat penggunaan fasilitas e-filing dalam penyampaian SPT secara online di Kantor Pelayanan Pajak Pratama Badung Utara dan Badung Selatan. Hasil ini menerima hipotesis keempat $\left(\mathrm{H}_{4}\right)$.

\section{Pembahasan}

Berdasarkan analisis penelitian didapatkan beberapa temuan dalam penelitian ini. Temuan pertama berkaitan dengan pengaruh persepsi kegunaan terhadap minat penggunaan fasilitas e-filing dalam penyampaian SPT secara online. Hasil uji hipotesis menunjukkan bahwa persepsi kegunaan berpengaruh positif terhadap minat penggunaan fasilitas e-filing dalam penyampaian SPT secara online di Kantor Pelayanan Pajak Pratama Badung Utara dan Badung Selatan. Hasil ini menjelaskan bahwa wajib pajak dapat menggunakan dengan baik fasilitas e-filing dalam penyampaian SPT secara online yang dapat memberikan manfaat sesuai harapan sehingga meningkatkan minat penggunaan fasilitas $e$-filing dalam penyampaian SPT secara online (Aji et al., 2022; Asih et al., 2019). Persepsi terhadap kegunaan dapat didefinisikan sebagai suatu ukuran dimana penggunaan suatu teknologi dipercaya akan mendatangkan manfaat bagi orang yang menggunakannya (Chusaeni \& Oktaviani, 2018; Susanto \& Jimad, 2019). Individu yang merasa semakin mudah menggunakan internet, akan mempengaruhi minatnya untuk bertransaksi secara online karena merasa semakin mudah mendapatkan manfaat dari teknologi tersebut (Marias, 2020; Utami, 2020). Persepsi kegunaan secara langsung dapat mempengaruhi niat untuk mencoba dan menggunakan sistem $e$-filing (Budiatin \& Rustiyaningsih, 2021; Widiastutik \& Oktaviani, 2020). Jika wajib pajak merasakan manfaatnya, ia akan berniat menggunakan sistem $e$-filing, sebaliknya jika wajib pajak tidak merasakan manfaat sistem $e$-filing, maka wajib pajak tersebut tidak akan berniat atau berminat untuk menggunakannya (Hasari, 2019).

Temuan kedua berkaitan dengan pengaruh persepsi kemudahan terhadap minat penggunaan fasilitas e-filing dalam penyampaian SPT secara online. Hasil uji hipotesis menunjukkan bahwa persepsi kemudahan berpengaruh positif terhadap minat penggunaan fasilitas e-filing dalam penyampaian SPT secara online di Kantor Pelayanan Pajak Pratama Badung Utara dan Badung Selatan. Pernyataan ini 
menjelaskan bahwa wajib pajak dapat dengan baik menggunakan fasilitas e-filing dalam penyampaian SPT secara online sehingga lebih mudah dan cepat serta mengurangi biaya administrasi jika dibandingkan dengan melaporkan SPT secara manual (Deffira \& Kurniawan, 2021; Nur \& Valentinus, 2020). Hal ini berpengaruh terhadap meningkatnya minat penggunaan fasilitas e-filing dalam penyampaian SPT secara online (Nurhayati \& Hidayat, 2019). Persepsi kemudahan penggunaan didefinisikan sebagai suatu tingkat atau keadaan dimana seseorang yakin bahwa dengan menggunakan sistem tertentu tidak diperlukan usaha apapun (free of effort) atau dengan kata lain teknologi tersebut dapat dengan mudah dipahami oleh pengguna (Alvin \& Kurniawati, 2019; Hasiara \& Kasim, 2020). Pengguna cenderung berminat untuk menggunakan suatu aplikasi yang dianggap sebagai sesuatu yang mereka yakini akan membantu kinerja mereka dalam melakukan pekerjaan (Chusaeni \& Oktaviani, 2018; Pramesti et al., 2021). Kemudahan penggunaan e-filing didefinisikan adalah lebih mudah dan cepat sehingga akan mengurangi biaya administrasi apabila melaporkan SPT secara manual sehingga akan mempengaruhi minat penggunaan $e$ filing dalam penyampaian SPT secara online (Anisa \& Suprajitno, 2020).

Temuan ketiga berkaitan dengan pengaruh kesiapan teknologi informasi wajib pajak terhadap minat penggunaan fasilitas $e$-filing dalam penyampaian SPT secara online. Hasil uji hipotesis menunjukkan bahwa kesiapan teknologi informasi wajib pajak berpengaruh positif terhadap minat penggunaan fasilitas e-filing dalam penyampaian SPT secara online di Kantor Pelayanan Pajak Pratama Badung Utara dan Badung Selatan. Pernyataan ini menjelaskan bahwa kesiapan wajib pajak adalah baik dalam menggunakan teknologi informasi sehingga meningkatkan minat penggunaan fasilitas e-filing dalam penyampaian SPT secara online (Lestari \& Kholis, 2020; Pu'o et al., 2018). Kesiapan teknologi informasi wajib pajak dilakukan secara efektif oleh pegawai perpajakan melalui serangkaian tindakan agar wajib pajak melunasi hutang pajaknya (Mokoagow et al., 2021). Kesiapan teknologi informasi pada dasarnya berhubungan langsung dengan kemajuan pola pikir individu (Chusaeni \& Oktaviani, 2018; Pu'o et al., 2018). Ini berarti semakin individu siap menerima teknologi yang baru berarti semakin maju pemikiran individu tersebut karena mampu beradaptasi dengan perkembangan teknologi (Asih et al., 2019). Apabila individu siap menerima adanya teknologi baru, maka individu pasti akan berminat menggunakan teknologi tersebut (Simu \& Hariadi, 2021). Sebaliknya jika individu tersebut tidak siap dan lebih nyaman menggunakan cara yang lama yaitu cara konvesional maka individu tersebut kurang berminat menggunakan teknologi baru (Sarroh, 2019).

Temuan keempat berkaitan dengan pengaruh efektivitas sistem terhadap minat penggunaan fasilitas e-filing dalam penyampaian SPT secara online. Hasil uji hipotesis menunjukkan bahwa efektivitas sistem berpengaruh positif terhadap minat penggunaan fasilitas e-filing dalam penyampaian SPT secara online di Kantor Pelayanan Pajak Pratama Badung Utara dan Badung Selatan. Pernyataan ini menjelaskan bahwa efektivitas sistem fasilitas $e$-filing adalah efektif mampu meningkatkan minat penggunaan fasilitas e-filing dalam penyampaian SPT secara online (Utomo et al., 2020). Efektivitas sistem merupakan informasi yang harus sesuai dengan kebutuhan pemakai dalam mendukung suatu proses bisnis, termasuk didalamnya informasi tersebut harus disajikan dalam waktu yang tepat, format yang tepat sehingga mudah dipahami, konsisten dengan format sebelumnya, isinya sesuai dengan kebutuhan saat ini dan lengkap atau sesuai dengan kebutuhan dan ketentuan (Alvin \& Apollo, 2020; Maria \& Nurlaela, 2020). Jika wajib pajak menyimpulkan penggunaan e-filing memiliki efektivitas sistem dalam pelaporan SPTnya, maka efektivitas sistem berpengaruh terhadap minat wajib pajak dalam melaporkan SPTnya menggunakan $e$-filing (Budiatin \& Rustiyaningsih, 2021).

Hasil yang diperoleh dalam penelitian ini sejalan dengan hasil penelitian terdahulu yang juga mengungkapkan bahwa faktor yang mempengaruhi minat wajib pajak dapat dilihat dari beberapa persepsi yakni persepsi kegunaan, kemudahan, kerahasiaan, kerumitan, kesiapan teknologi informasi berpengaruh signifikan terhadap minat wajib pajak orang pribadi dalam menggunakan $e$-filing (Pu'o et al., 2018). Hasil penelitian lainnya juga mengungkapkan bahwa E-filing untuk hotel dan restoran di wilayah perbatasan RIRDTL, Pengetahuan pajak tidak berpengaruh positif dan tidak signifikan terhadap minat penggunaan system e-filing untuk hotel dan restoran di wilayah perbatasan RI-RDTL, Persepsi kemudahan berpengaruh positif dan signifikan terhadap minat penggunaan system e-filing untuk hotel dan restoran di wilayah perbatasan RI-RDTL, Pemahaman teknologi informasi tidak memiliki pengaruh positif dan tidak signifikan terhadap minat penggunaan system e-filing untuk hotel dan restoran di wilayah perbatasan RI-RDTL (Simu \& Hariadi, 2021). Penelitian selanjutnya juga mengungkapkan hal serupa yakni persepsi kemudahan, persepsi kegunaan serta keamanan dan kerahasiaan berpengaruh positif terhadap minat wajib pajak orang pribadi menggunakan e-filing, pemahaman internet tidak mampu memoderasi pengaruh persepsi kemudahan dan persepsi kegunaan terhadap minat menggunakan e-filing sedangkan pemahaman internet mampu memoderasi pengaruh keamanan dan kerahasiaan terhadap minat menggunakan e-filing (Asih et al., 2019). Sehingga berdasarkan hasil tersebut dapat dikatakan bahwa terdapat 5 faktor yang 
mempangaruhi minat Penggunaan Fasilitas E-Filing dalam Penyampaian SPT Secara Online diantaranya yakni faktor kegunaan, kemudahan, kerahasiaan, kerumitan, kesiapan teknologi informasi.

\section{SIMPULAN}

Berdasarkan hasil analisis data dan pembahasan, maka didapat simpulan bahwa persepsi kegunaan, kemudahan, kesiapan teknologi, dan efektifitas sistem memberikan pengaruh positif terhadap minat penggunaan fasilitas e-filing dalam penyampaian SPT secara online. Hal ini berarti bahwa semakin tinggi persepsi kegunaan, kemudahan, kesiapan teknologi, dan efektifitas sistem maka akan semakin tinggi pula minat penggunaan $e$-filing masyarakat wajib pajak.

\section{DAFTAR PUSTAKA}

Aji, R. P., Puti, A. A., \& Sari, D. P. P. (2022). Determinan Kepuasan Pengguna E-Filing Masa Pandemi Covid19. Jurnal Ekonomi Dan Bisnis Dharma Andalas, 24(1). https://doi.org/10.47233/jebd.v24i1.341.

Alvin, F., \& Apollo. (2020). Pengaruh Modernisasi Sistem Administrasi Perpajakan, Sanksi Pajak Terhadap Kepatuhan Wajib Pajak Orang Pribadi Pada Kpp Pratama. Jurnal Ekonomi Manajemen Sistem Informasi, 1(3), 229-237. https://doi.org/10.31933/jemsi.v1i3.103.

Alvin, \& Kurniawati, K. (2019). Analisis Penerimaan Audit Software Bagi Auditor Eksternal Dengan Menggunakan Pendekatan Technology Acceptance Model (Tam). Balance Vocation Accounting Journal, 3(2), 1. https://doi.org/10.31000/bvaj.v3i2.2236.

Anisa, R., \& Suprajitno, D. (2020). Pengaruh Persepsi Kebermanfaatan, Persepsi Kemudahan Penggunaan, dan Kepuasan Wajib Pajak Terhadap Penggunaan E-Filing Bagi Wajib Pajak di Kebumen. Jurnal Ilmiah Mahasiswa Manajemen, Bisnis Dan Akuntansi (JIMMBA), 2(4), 595-609. https://doi.org/10.32639/jimmba.v2i4.644.

Asih, K. A. A., Yuesti, A., \& Sudiartana, I. M. (2019). Faktor-Faktor Yang Mempengaruhi Minat Wajib Pajak Orang Pribadi Menggunakan E-Filing Untuk Pelaporan Pajaknya Dengan Pemahaman Internet Sebagai Variabel Moderasi (Studi Pada Wajib Pajak Orang Pribadi di Wilayah Kabupaten Gianyar). JSAM Jurnal Sains, Akuntansi Dan Manajemen), 1(4), 505-549. https://doi.org/10.1234/jsam.v4i1.75.

Biettant, R., Bieattant, L., Sugondo, L. Y., Pujianthi, E., Andrian, P. D., \& Charlie, C. (2020). Meningkatkan Kompetensi Perpajakan Bagi Guru-Guru Akuntansi SMK Di Wilayah Jakarta Timur. Jurnal Komunitas: Jurnal Pengabdian Kepada Masyarakat, 2(2), 145-151. https://doi.org/10.31334/jks.v2i2.737.

Budiatin, E. A., \& Rustiyaningsih, S. (2021). Pengaruh persepsi kegunaan, persepsi kemudahan, faktor sosial, dan kondisi yang memfasilitasi terhadap minat penggunaan e- filing di kota madiun ( studi kasus di kpp pratama madiun). Jurnal Riset Manajemen Dan Akuntansi, 9(2). https://www.researchgate.net/profile/JrmaJrma/publication/357149314a83a6251b553ac7256f.

Chrisandita, G. M., \& Sukartha, I. M. (2021). Pengaruh Persepsi Kebermanfaatan, Persepsi Kemudahan, dan Persepsi Efisien Wajib Pajak Orang Pribadi pada Penggunaan E-Filing. Syntax Literate; Jurnal Ilmiah Indonesia, 6(7), 3215. https://doi.org/10.36418/syntax-literate.v6i7.3520.

Chusaeni, B. F., \& Oktaviani, R. M. (2018). Penguasaan Teknologi Informasi sebagai Pemoderasi Kecenderungan Wajib Pajak Menggunakan E-Filing. Jurnal Ekonomi Modernisasi, 14(1), 16-27. https://doi.org/10.21067/jem.v14i1.2376.

Deffira, A., \& Kurniawan, R. (2021). Analisis Perbedaan Tingkat Kepatuhan Wajib Pajak Sebelum Dan Sesudah Penerapan E-Filing di Kota Padang. Ekonomis: Journal of Economics and Business, 5(1), 176. https://doi.org/10.33087/ekonomis.v5i1.313.

Dewi, M. A. C. (2019). Pengaruh Persepsi Kegunaan, Persepsi Kemudahan, Keamanan dan Kerahasiaan, Tingkat Kesiapan Teknologi Informasi, dan Kepuasan Pengguna Wajib Pajak terhadap Intensitas Perilaku Wajib Pajak Dalam Penggunaan E-Filing. JSAM (Jurnal Sains, Akuntansi Dan Manajemen), 1(3), 317-368. https://doi.org/10.1234/jsam.v1i3.66.

Dewi, S. (2021). Pengembangan Model Konseptual Niat Pembayaran Pajak Pelaku E-Commerce. Jurnal Owner, 5(2), 442-449. https://doi.org/10.33395/owner.v5i2.447.

Harefa, M. (2019). Pengaruh Kebijakan Dana Bagi Hasil Terhadap Penerimaan Daerah Di Provinsi Kalimantan Timur. Jurnal Ekonomi Dan Kebijakan Publik, 9(2), 147-160. https://doi.org/10.22212/jekp.v9i2.1159.

Harjowiryono, M. (2019). Analisis faktor-faktor yang memengaruhi kepatuhan bendahara pemerintah dalam penyetoran pajak. Indonesian Treasury Review Jurnal Perbendaharaan Keuangan Negara Dan 
Kebijakan Publik, 4(3), 195-217. https://doi.org/10.33105/itrev.v4i3.156.

Haryaningsih, S., \& Juniwati, J. (2020). Implementasi Program Electronic Filing (E-Filing) Dalam Upaya Peningkatan Kepatuhan Wajib Pajak Orang Pribadi Kota Pontianak Kalimantan Barat Dengan Pemahaman Menuju Era Ekonomi Digital. Jurnal Reformasi Administrasi, 8(1). https://doi.org/10.31334/reformasi.v8i1.1435.

Hasari, N. K. Y. (2019). Faktor-Faktor yang Mempengaruhi Intensitas Perilaku Dalam Penggunaan E-Filing terhadap Wajib Pajak Orang Pribadi Pada KPP Pratama Badung Selatan. Jurnal Sains, Akuntansi Dan Manajemen, 1(2), 41-77. https://doi.org/10.1234/jasm.v1i2.33.

Hasiara, L. O., \& Kasim, M. (2020). Faktor-Faktor Yang Mempengaruhi Minat Mahasiswa Menggunakan Electronic MoneY. Jurnal Akuntan Multi Dimensi, 8(1). https://doi.org/10.96964/jamdi.v3i3.757.

Irawati, W., Akbar, Z., Wulandari, R., \& Barli, H. (2020). Analisis Profitabilitas, Leverage, Pertumbuhan Penjualan Dan Kepemilikan Keluarga Terhadap Penghindaran Pajak. Jurnal Akuntansi Kajian Ilmiah Akuntansi (JAK), 7(2), 190-199. https://doi.org/10.30656/jak.v7i2.2307.

Kolatung, J. F. (2021). Analisis Tingkat Kepatuhan Wajib Pajak Bumi Dan Bangunan Di Kota Manado. Jurnal Emba: Jurnal Riset Ekonomi, Manajemen, Bisnis Dan Akuntansi, 9(2). https://doi.org/10.35794/emba.v9i2.33926.

Lestari, A., \& Kholis, N. (2020). Pengaruh Persepsi Pemahaman Pajak, Kebermanfaatan, Kemudahan Penggunaan, Faktor Sosial Dan Kesiapan Teknologi Informasi Terhadap Penggunaan E-Filing (Studi pada Wajib Pajak Badan di KPP Pratama Surakarta). Jurnal Ilmiah Akuntansi Dan Teknologi, 12(1), 117. https://doi.org/10.31253/aktek.v12i1.369.

Maria, M. P., \& Nurlaela, S. (2020). Sikap, Kesadaran, Pengetahuan Dan Kepatuhan Wajib Pajak Di Masa Pandemi Covid-19. Jurnal Inovasi Akutansi, Keuangan Dan Perpajakan, 2(2). https://doi.org/10.35314/iakp.v2i2.2279.

Marias. (2020). Persepsi Kemudahan Penggunaan, Efektivitas,Dan Risiko Berpengaruh Terhadap Minat BertransaksiMenggunakan Financial Technology. Jurnal Adminnistrasi Kantor, 8(2), 139-152. https://doi.org/10.51211/jak.v8i2.1448.

Maryan, N. K. J. (2019). Terhadap Kepatuhan Wajib Pajak Dengan Penggunaan E-Filing Sebagai Variabel Intervening Pada Kpp Pratama Gianyar. JSAM (Jurnal Sains, Akuntansi Dan Manajemen), 1(2). https://doi.org/10.1234/jasm.v1i2.35.

Mineri, M. F., \& Paramitha, M. (2021). Pengaruh Pajak, Tunneling Incentive, Mekanisme Bonus Dan Profitabilitas Terhadap Transfer Pricing. Jurnal Analisa Akuntansi Dan Perpajakan, 5(1). https://doi.org/10.25139/jaap.v5i1.3638.

Mokoagow, S., Nangoy, G., \& Warongan, essy D. L. (2021). Analisis Kepatuhan Pengusaha Kena Pajak (Pkp) Dalam Melaksanakan Kewajiban Perpajakannya Berdasarkan Modernisasi Sistem Administrasi Perpajakan Pada Sektor Pajak Pertambahan Nilai (Ppn) Di Manado. Jurnal Riset Akuntansi Dan Auditing “Goodwill," 12(2). https://doi.org/10.35800/jjs.v12i2.36316.

Muhammad, F. H., \& Mildawati, T. (2020). Pengaruh Penerapan E-Filing Dan Kualitas Pelayanan Pembayaran Perpajakan. Ilmu Dan Riset Akuntansi, 9(1), 1-19. http://jurnalmahasiswa.stiesia.ac.id/index.php/jira/article/view/2781/2791.

Nasution, A., \& Ferrian, M. (2017). Dampak Pengetahuan Pajak Dan Kualitas Pelayanan Petugas Pajak Terhadap Kepatuhan Wajib Pajak Orang Pribadi. Jurnal Akuntansi Bisnis Dan Publik, 1(1), 207-224. https://journal.pancabudi.ac.id/index.php/akuntansibisnisdanpublik/article/view/447/423.

Nur, T. F., \& Valentinus, F. (2020). Kelemahan Penggunaan E-Filling Pada Pengisian Surat Pemberitahuan Tahunan Pajak Penghasilan Orang Pribadi Dengan Periode Penghasilan Kurang Dari 12 Bulan. Jurnal Administrasi Bisnis Terapan, 2(2). https://doi.org/10.7454/jabt.v2i2.95.

Nurhayati, E., \& Hidayat, N. (2019). Analisis Perbandingan Prediksi Keberterimaan E-Filing Dengan E-Form Dalam Penyampaian Surat Pemberitahuan (Spt) Tahunan 1770/1770s. Jae (Jurnal Akuntansi Dan Ekonomi), 4(2), 1-13. https://doi.org/10.29407/jae.v4i2.12720.

Pramesti, R. A., Sukirman, S., \& Bawono, I. R. (2021). Persepsi Kegunaan, Kemudahan, Keamanan dan Kerahasiaan, Serta Kepuasan Wajib Pajak Pengguna E-Filing dan Non E-Filing untuk Pajak Tahunan Orang Pribadi. Jurnal Perspektif Ekonomi Darussalam, 7(1), 94-112. https://doi.org/10.24815/jped.v7i1.17000.

Pu'o, S., Sondakh, J. J., \& Budiarso, N. S. (2018). Analisis Faktor-Faktor Yang Mempengaruhi Minat Wajib Pajak Orang Pribadi Dalam Menggunakan E-Filing Sebagai Sarana Pelaporan SPT Pada Kpp Pratama Poso. Going Concern: Jurnal Riset Akuntansi, 13(04). https: //doi.org/10.32400/gc.13.03.20185.2018.

Rahmi, N., Pohan, C. A., Arimbhi, P., Mansur, M., \& Zulkifli, Z. (2020). Pelatihan Pembukuan Keuangan Sederhana dalam Rangka Pelaksanaan Kebijakan Pajak yang Baru (PP Nomor: 23/2018) Untuk Pelaku UMKM Naik Kelas di Kota Depok. Jurnal Komunitas : Jurnal Pengabdian Kepada Masyarakat, 
2(2), 152-158. https://doi.org/10.31334/jks.v2i2.738.

Rusli, Y. M., \& Nainggolan, P. (2021). Pentingnya Pengetahuan Pajak Dan Sosialisasi Pajak Kepada Calon Wajib Pajak Masa Depan. Jurnal Pengabdian Dan Kewirausahaan, 5(2). https://doi.org/10.30813/jpk.v5i2.2989.

Sakir, A. R., Sagita, H. S., \& Arni, R. S. (2021). Efektivitas Pemungutan Pajak Kendaraan Bermotor (PKB) Kendaraan Dinas Dalam Meningkatkan Pajak Asli Daerah. Jurnal Syntax Fusion, 1(10), 483-489. https://doi.org/10.54543/fusion.v1i10.74.

Salamah, B., \& Furqon, I. K. (2020). Pengaruh Pandemi Covid Terhadap Penerimaan Pajak di Negara Indonesia Pada Tahun 2020. Perpajakan Dan Auditing, 1(2), 277-289. http://pub.unj.ac.id/journal/index.php/japa.

Sarroh, M. (2019). Kepuasan Wajib Pajak Orang Pribadi Terhadap Penggunaan E-Billing. Jurnal Ilmu Dan Riset Akuntansi, $1(1), \quad 218-229$. http://jurnalmahasiswa.stiesia.ac.id/index.php/jira/article/view/2836/2846.

Simu, S., \& Hariadi, S. (2021). Faktor-Faktor Yang Mempengaruhi Minat Penggunaan Sistem E- Filing Untuk Hotel Dan Restoran Di Wilayah Perbatasan RI-RDTL. JSMA (Jurnal Sains Manajemen Dan Akuntansi), 13(2), 75-86. https://doi.org/10.37151/jsma.v13i2.69.

Sumarlan, A., Fraternesi, F., \& Wati, S. A. (2020). Kepatuhan Wajib Pajak Menggunakanan Sistem E-Filling (Studi Kasus Pada Kantor Pelayanan Pajak Pratama Wilayah Bengkulu). Jurnal Akuntansi, Keuangan Dan Teknologi Informasi Akuntansi, 1(1), 13-23. https: //doi.org/10.36085/jakta.v1i1.866.

Suparman, N. (2021). Dampak Pandemi Covid-19 terhadap Pengelolaan Keuangan Negara. Jurnal Perbendaharaan, Keuangan Negara Dan Kebijakan Publik, 6(1), 31-42. https://doi.org/10.33105/itrev.v6i1.261.

Surya, D., Hamdan, D., \& Muin, F. (2019). Tingkat Kesadaran Masyarakat Untuk Membayar Pajak Daerah Dalam Mendukung Pembangunan (Studi Di Wilayah Pemerintahan Kota Serang). Tirtayasa Ekonomika, 14(2), 310. https://doi.org/10.35448/jte.v14i2.6518.

Susanto, E., \& Jimad, N. (2019). Pengaruh Persepsi Penggunaan Technology Acceptance Model (TAM) Terhadap Penggunaan E-filling. Jurnal Akuntansi Peradaban, 5(1), 104-125. https://doi.org/10.24252/jiap.v5i1.10431.

Utami, A. R. H. (2020). Pengaruh presepsi kemudahan, kegunaan dan kepercayaan terhadap minat menggunakan e-commerce. Prisma (Platform Riset Mahasiswa Akuntansi), 1(6), 79-93. http://ojs.stiesa.ac.id/index.php/prisma/article/view/694/265.

Utomo, G. S., Titisari, K. H., \& Wijayanti, A. (2020). Pengaruh Kualitas E-Government Terhadap Kepuasan Pengguna E-Filing: Studi Kasus Wajib Pajak Di Surakarta. Jurnal Akuntansi Dan Bisnis: Jurnal Program Studi Akuntansi, 6(1), 13-21. https://doi.org/10.31289/jab.v6i1.2752.

Viva, A. A., Kowel, L. A. A., \& Kalangi, S. J. (2019). The Effect Of Taxpayer Knowledge, Taxpayer Awareness And Modernization Of Tax Administration System To Taxpayer Compliance Of Motor Vehicles In South Minahasa Regency. Jurnal EMBA, 7(3), 4251-4260. https://doi.org/10.35794/emba.v7i3.25060.

Widiastutik, A., \& Oktaviani, R. M. (2020). Pengaruh Pengalaman Dalam Memoderasi Persepsi Kemudahan Terhadap Intensitas Penggunaan E-Filing. Jurnal Akuntansi Dan Pajak, 21(01), 40-47. https://doi.org/10.29040/jap.v21i1.1033. 